MAKSIMUM: Media Akuntansi Universitas Muhammadiyah Semarang, Vol.10 (1) 2020, 1-11

https://jurnal.unimus.ac.id/index.php/MAX

Registered with the Indonesian Institute of Sciences with p-ISSN: $2087-$ 2836 and e-ISSN: 2580-9482

\title{
Faktor-Faktor Yang Mempengaruhi Kualitas Prosedur Pengendalian Internal Dan Perannya Dalam Memoderasi Hubungan Persepsi Keadilan Organisasi Terhadap Employee Fraud
}

\author{
Ika Hariyanti
}

Fakultas Ekonomi, Universitas AKI Semarang, Indonesia

\begin{abstract}
Info Article
History Article:

Submitted: 10 Januari

2020

Revised: 25 Januari

2020

Accepted: 30 Februari

2020

Keywords:

Internal control,

perception of justice,

employee fraud.

JEL classifications:

E62, G11, G34

Abstract

This research aims to analyze the perception of organizational justice on employee fraud moderated by the quality of the internal control procedures of manufacture company in Semarang. The factors which affect the quality of internal control procedures is ethical corporate environment, risk management training, internal audit activities, suitability compensation and power leadership. The population of this research is the top management level at the manufacture company in Semarang. The sampling technique is random sampling. 32 samples used in this research and OLS regression analysis with SPSS 19 version program. The results of this research verify that quality of internal control procedures positively moderate the relation between perception of organizational justice and employee fraud. Ethical corporate environment and risk management training has a positive and not significant to the quality of internal control procedures. Internal audit activities has positive and significant to the quality of internal control procedures. Suitability compensation and power leadership has a negative and significant to the quality of internal control procedures.
\end{abstract}

How to Cite: Hariyanti, I. (2020). Faktor-Faktor Yang Mempengaruhi Kualitas Prosedur Pengendalian Internal Dan Perannya Dalam Memoderasi Hubungan Persepsi Keadilan Organisasi Terhadap Employee Fraud. MAKSIMUM, Vol.1O(1), 1-11

\begin{tabular}{ll}
\hline${ }^{\circ}$ correspondence Address: Jl. Imam Bonjol No.15 - 17, Dadapsari, Kec. Semarang Utara, Kota & $2086-0668$ (P-ISSN) \\
Semarang, Jawa Tengah 50173 & $2337-5434$ (e-ISSN)
\end{tabular}

Institutional address: Universitas AKI, Semarang

E-mail: hariyanti@gmail.com 


\section{PENDAHULUAN}

Kasus kecurangan (fraud) memiliki dampak yang serius bagi organisasi. Di Indonesia, beragam praktik kecurangan (fraud) ditemukan, yang mungkin lebih dikenal dengan istilah korupsi. Fraud merupakan ancaman yang signifikan dan berkembang di seluruh dunia, menurut Seetharaman et al (2004), fraud mudah dilakukan, sedangkan pencegahan dan deteksi kejahatan perusahaan bukanlah tugas yang mudah. Employee fraud cenderung lebih sering terjadi pada perusahaan-perusahaan kecil karena kurangnya pemisahan tugas, namun terbuka untuk terjadi pada perusahaan besar karena kompleksitas dan volume transaksi yang besar, memungkinkan fraud tidak terdeteksi (Marden dan Edwards, 2005; Ziegenfuss, 1996). Pengendalian internal umumnya dianggap sebagai kunci pencegah fraud.

Penelitian ini dilakukan pada perusahaan industri besar dan sedang, khususnya perusahaan manufaktur di Semarang, karena Semarang merupakan kota besar dan ibu kota Jawa Tengah. Tercatat pada Direktori Perusahaan Besar dan Sedang Jawa Tengah Tahun 2009 Badan Pusat Statistik Jawa Tengah, ada 340 perusahaan besar dan sedang di Kota Semarang yang terbagi dalam 15 kecamatan yang ada di kota Semarang.

Pada penelitian ini, kesempatan untuk melakukan tindakan fraud mempunyai efek moderating pada hubungan antara persepsi keadilan organisasi dan employee fraud. Kualitas prosedur pengendalian internal merupakan proxy untuk mengukur kesempatan untuk fraud yang terjadi karena kualitas prosedur pengendalian internal yang kuat akan meminimalkan frekuensi fraud, sedangkan kualitas prosedur pengendalian internal yang rendah akan meningkatkan kesempatan fraud. Berdasarkan uraian di atas, hubungan antara persepsi keadilan organisasi dan employee fraud dimoderasi oleh kualitas prosedur pengendalian internal. Maka hipotesis pertama dalam penelitian ini adalah:

H1 : Ada interaksi yang signifikan antara persepsi karyawan bagi keadilan organisasi dan kualitas prosedur pengendalian internal mempengaruhi tindakan employee fraud.

H2a :Ada hubungan positif antara ethical corporate environment terhadap kualitas prosedur pengendalian internal.

$\mathrm{H} 2 \mathrm{~b}$ :Ada hubungan positif antara Risk Management Training terhadap kualitas prosedur pengendalian internal.

H2c :Ada hubungan positif antara internal audit activities terhadap kualitas prosedur pengendalian internal.

H2d :Ada hubungan positif antara kompensasi gaji terhadap kualitas prosedur pengendalian internal.

H2e :Ada hubungan positif antara power leadership terhadap kualitas prosedur pengendalian internal.

\section{METODE PENELITIAN \\ Disain Penelitian}

Penelitian ini merupakan penelitian kuantitatif yakni penelitian yang menggunakan data sistematis dan fenomena, tujuannya untuk mengembangkan dan menggunakan model-model matematis, teori-teori dan hipotesis. Adapun pengambilan data pada penelitian ini dengan kuesioner atau angket agar lebih mudah dan fleksibel bagi responden sehingga diharapkan dapat memberikan informasi yang sebenar-benarnya. Kuesioner atau angket diantar langsung kepada responden. Responden dalam penelitian ini adalah para top management.

\section{Populasi dan sampel}

Populasi pada penelitian ini adalah perusahaan manufaktur di Semarang, yang terdaftar dalam Direktori Perusahaan Besar dan Sedang Jawa Tengah Tahun 2009 yang dikeluarkan oleh Badan Pusat Statistik. Jumlah sampel pada penelitian ini sebanyak 32. 
Hasil tersebut dapat digunakan, karena telah memenuhi syarat sampel besar yaitu diatas 30 puluh. Jumlah tersebut diperoleh dari jumlah kuesioner yang disebar sebanyak 90 buah yang hanya kembali sampai tanggal 20 September 2012 sebanyak 32 kuesioner. Teknik Pengambilan sampel didasarkan pada teknik sampel acak dengan memberikan kuesioner pada masing-masing perusahaan diambil enam orang responden yaitu manajemen tingkat atas (top management) seperti Financial Controller, Manajer Keuangan, Direktur, General Manager, Internal Auditor, dan Karyawan Staff Keuangan (finance and accounting).

\section{Teknik Analisis}

Penelitian ini menguji pengaruh kelima variabel independen, yaitu lingkungan etik organisasi (ethical corporate environment), pelatihan manajemen risiko (risk management training), kegiatan audit internal (internal audit activities), kompensasi gaji dan Power Leadership terhadap kualitas prosedur pengendalian internal, serta pengaruh persepsi keadilan organisasi (organizational justice perceptions) terhadap fraud yang dimoderasi oleh kualitas prosedur pengendalian internal sehingga teknik analisis yang digunakan berupa regresi. Data penelitian yang akan dianalisis menggunakan alat analisis yang terdiri dari:

\section{Statistik Deskriptif}

Untuk memberikan gambaran mengenai demografi responden penelitian ini (umur, jenis kelamin, tingkat pendidikan, jabatan dan lama bekerja) dan deskripsi mengenai variabel-variabel penelitian. Peneliti menggunakan tabel distribusi frekuensi absolute yang menunjukkan angka rata-rata dan standar deviasi. Menurut Hair et al (1996) kualitas data yang dihasilkan dari penggunaan instrumen penelitian dapat dievaluasi melalui uji reliabilitas dan validitas. Fungsi pengujian tersebut untuk mengetahui konsistensi dan akurasi data yang dikumpulkan dari penggunaan instrumen. Prosedur pengujian kualitas data adalah sebagai berikut:

\section{Uji Validitas dan Reabilitas}

Uji validitas dapat dilakukan dengan melihat nilai correlated item. Total Correlation dengan kriteria sebagai berikut: Jika nilai $r$ hitung lebih besar dari $r$ tabel dan nilainya positif, maka butir pertanyaan atau indikator tersebut dikatakan "valid" (Ghozali, 2011). Namun sebaliknya, jika nilai $r$ hitung lebih kecil dari $r$ tabel, maka pertanyaan tersebut dapat dikatakan "tidak valid". Menurut Ghozali 2011 suatu kuesioner dikatakan reliable atau handal jika jawaban seseorang terhadap pertanyaan adalah konsisten dari waktu ke waktu. Pengujian ini dilakukan dengan menghitung koefisien cronbach alpha dari masingmasing instrument dalam suatu variabel. Instrumen dapat dikatakan handal (reliable) bila memiliki koefisien cronbach alpha lebih dari 0,70 (Nunnally, 1994 dalam Ghozali, 2011).

\section{Uji Asumsi Klasik \\ Uji Normalitas}

Uji normalitas bertujuan untuk menguji apakah dalam sebuah regresi, model statistik, variabel dependen, variabel independen atau keduanya mempunyai distribusi normal ataukah tidak mempunyai distribusi normal. Ada dua cara untuk mendeteksi distribusi normal yaitu dengan analisis grafik dan uji statistik.

\section{Multikolonearitas}

Pengujian asumsi klasik selanjutnya yaitu uji multikolinieritas (multicoliniearity) antara variabel - variabel independen yang masuk ke dalam model. Metode untuk mengetahui adanya multikolinieritas dilakukan dengan uji Rasio VIF atau Variance Inflation Factor yang dirumuskan dengan :

\section{VIF $=1 /$ Tolerance Uji Heteroskedastisitas}


Pengujian heteroskedastisitas ini digunakan untuk mengetahui adanya heteroskedastisitas dengan Glejser Test yang dihitung dengan rumus :

$\left[\mathrm{e}_{\mathbf{i}}\right]=\boldsymbol{\beta} \boldsymbol{i} \boldsymbol{X} \boldsymbol{i}+\boldsymbol{v i}$

Dimana :

$\mathrm{e}_{\mathbf{i}}$ : residuals

$X i$ : variabel independen yang diperkirakan mempunyai hubungan erat dengan variance

vi : unsur kesalahan

Jika secara statistik ditemukan hubungan yang signifikan, maka dapat disimpulkan bahwa terdapat heteroskedastisitas dalam varian kesalahan, demikian sebaliknya.

\section{Uji Hipotesis}

\section{Analisis Regresi Logistik}

Pengujian model H1 menggunakan analisis regresi logistic. Variabel independen employee fraud kegagalan terhadap kualitas prosedur pengendalian internal, persepsi keadilan organisasi dan interaksi perkalian panjang antara kedua variabel. Persamaan regresinya adalah sebagai berikut :

$\operatorname{Pr}(\mathrm{Y}=1)=\mathrm{F}[\beta 0+\beta 1 \mathrm{X} 1+\beta 2 \mathrm{X} 2+\beta 3 \mathrm{X} 1 * \mathrm{X} 2]$

Dimana:

$\operatorname{Pr} \quad$ : Employee fraud;

$\mathrm{X} 1$ : Pengendalian internal;

$\mathrm{X} 2$ : Persepsi karyawan

$\mathrm{X} 1 * \mathrm{X} 2 \quad$ : Interaksi;

\section{Analisis Regresi Berganda}

Variabel dependen, kualitas prosedur pengendalian internal diregresikan dengan lima variabel independen yaitu, ethical corporate environment, risk management training, internal audit activities, kompensasi gaji dan power leadership.

$Y=\beta 0+\beta 1 X 1+\beta 2 X 2+\beta 3 X 3+\beta 4 X 4+\beta 5 X 5$

Dimana :

Y : Kualitas Prosedur Pengendalian Internal

$\mathrm{X} 1$ : Ethical Corporate Environment

X2 : Risk Management Training

$\mathrm{X} 3$ : Aktivitas Internal Audit

$\mathrm{X} 4$ : Kesesuaian Kompensasi

X5 : Power Leadership

$\beta 0$ : Konstanta

$\beta 1-6$ :Koefisien regresi variabel independen

\section{HASIL DAN PEMBAHASAN}

\section{Gambaran Umum}

Dalam penelitian ini kuesioner yang disebarkan sebanyak 90 buah. Berikut rincian pengiriman dan pengembalian kuesioner yang ditunjukkan dalam tabel berikut:

Tabel 1. Persebaran Level Jabatan Responden

\begin{tabular}{clcc}
\hline No & Level / jabatan & $\begin{array}{c}\text { Kuesioner } \\
\text { dibagi }\end{array}$ & $\begin{array}{c}\text { Kuesioner } \\
\text { kembali }\end{array}$ \\
\hline 1 & Finance Controller & 17 & - \\
2 & Manajer Keuangan & 17 & 3 \\
3 & Internal Audit & 17 & 8 \\
4 & Staff Finance \& Accounting & 17 & 17 \\
5 & General Manager & 17 & 1
\end{tabular}




\begin{tabular}{llcc}
6 & Direktur & 17 & - \\
& Jumlah Keseluruhan & 102 & 32 \\
\hline
\end{tabular}

Sumber : data primer yang diolah, 2012

\section{Gambaran Umum Responden}

Profil responden berdasarkan umur, jenis kelamin, pendidikan, jabatan dan lama bekerja pada perusahaan manufaktur di Semarang dijelaskan dalam tabel berikut ini:

Tabel 2. Demografi Responden

\begin{tabular}{|c|c|c|}
\hline Keterangan & Jumlah & Persentase \\
\hline Laki-laki & 11 & $34,37 \%$ \\
\hline Perempuan & 21 & $65,63 \%$ \\
\hline \multicolumn{3}{|l|}{ Umur } \\
\hline 20-25 tahun & 3 & $9,37 \%$ \\
\hline 26-30 tahun & 11 & $34,37 \%$ \\
\hline 31-35 tahun & 8 & $25 \%$ \\
\hline 36-40 tahun & 6 & $18,75 \%$ \\
\hline 41-45 tahun & 2 & $6,25 \%$ \\
\hline 46-50 tahun & 1 & $3,13 \%$ \\
\hline 51 tahun keatas & 1 & $3,13 \%$ \\
\hline \multicolumn{3}{|l|}{ Pendidikan } \\
\hline D3 & 10 & $31,25 \%$ \\
\hline $\mathrm{S} 1$ & 21 & $65,62 \%$ \\
\hline $\mathrm{S} 2$ & 1 & $3,13 \%$ \\
\hline
\end{tabular}

Jabatan

Finance Controller

Manager Keuangan

$3 \quad 9,375 \%$

Internal Audit

8

$25 \%$

Staff Finance \& Accounting

17

$53,12 \%$

General Manager

1

$3,13 \%$

Direktur

3

$9,375 \%$

\section{Lama Bekerja}

$<5$ tahun

$43,75 \%$

5 - 15 tahun

12

$37,5 \%$

$>15$ tahun

6

$18,75 \%$

Jumlah Responden

32

$100 \%$

Sumber: Data diolah 
Statistik Deskriptif Variabel Penelitian

Tabel 3. Hasil Pengujian Statistik Deskriptif

\begin{tabular}{lllll}
\hline Var & Min & Max & Mean & Std. Dev \\
\hline ECE & 17 & 25 & 22.31 & 2.348 \\
RMT & 19 & 25 & 22.31 & 2.235 \\
IAA & 19 & 25 & 21.59 & 1.965 \\
KK & 19 & 25 & 21.38 & 1.680 \\
PL & 15 & 25 & 0,918 & 2.780 \\
KPPI & 30 & 40 & 34.28 & 3.429 \\
PKO & 29 & 52 & 38.66 & 6.880 \\
EF & 25 & 40 & 32.37 & 4.218 \\
\hline
\end{tabular}

Sumber: Data diolah

\section{Uji Kualitas Data}

Pada tahapan ini dilakukan pengujian terhadap kualitas data yang akan diolah dalam analisis statistik. Ada dua kriteria yang digunakan yaitu uji validitas dan uji reliabilitas.

\section{Uji Validitas}

Uji validitas digunakan untuk mengukur valid atau tidaknya kuesioner. Kemampuan kuesioner untuk mengungkapkan suatu variabel atau konstruk yang seharusnya diukur dari hasil signifikansi dari uji pearson correlation.

Tabel 4. Hasil pengujian korelasi

\begin{tabular}{lcccccc}
\hline \multicolumn{6}{l}{ Corelation } \\
\hline & KPPI & ECE & RMT & IAA & KK & PL \\
\hline KPPI & 1.000 & .345 & .439 & .755 & .115 & .225 \\
ECE & .345 & 1.000 & .221 & .329 & -.055 & .597 \\
RMT & .439 & .221 & 1.000 & .544 & .389 & .305 \\
IAA & .755 & .329 & .544 & 1.000 & .331 & .284 \\
KK & .115 & -.055 & .389 & .331 & 1.000 & .197 \\
PL & .225 & .597 & .305 & .284 & .197 & 1.000 \\
\hline
\end{tabular}

Sumber Data diolah

\section{Uji Reliabilitas}

Tabel 5. Hasil Pengujian Reliabilitas Statistik

\section{Reliability Statistics}

Cronbach's Alpha Cronbach's Alpha Based on Standardized Items N of Items
.920
.929

Sumber Data diolah

Nilai Cronbach Alpha dalam penelitian ini adalah 92\% yang menurut kriteria Nunnally (1994) reliable. 


\section{Analisis Data}

Uji Asumsi Klasik

Uji Normalitas

Uji normalitas menggunakan analisis grafik histogram dan normal probability plot serta analisis statistik One-Sample Kolmogorov-Smirnov Test. Hasil pengujian adalah sebagai berikut:

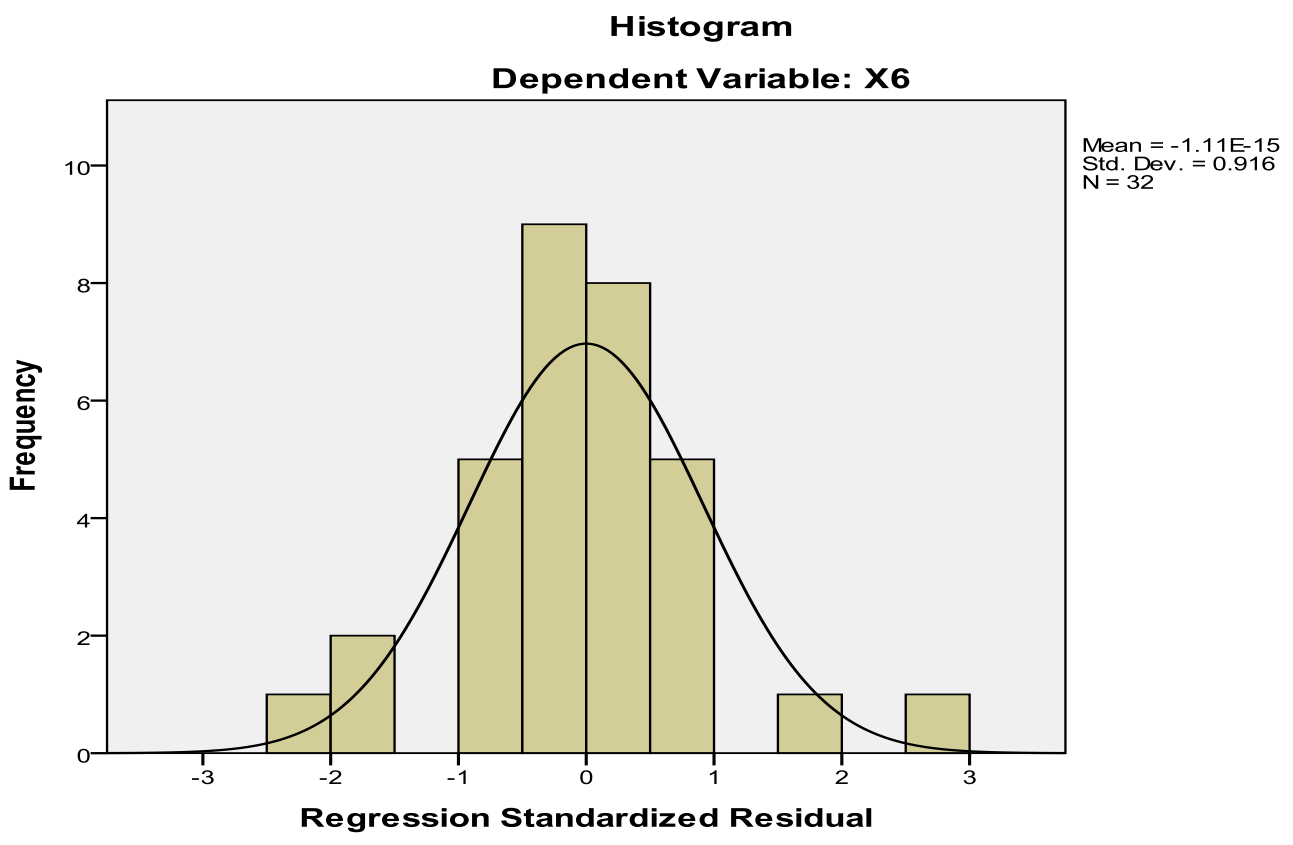

Gambar 1. Histogram normalitas

Berdasarkan gambar diatas terlihat bahwa histogram mempunyai kemiripan bentuk dengan kurva normal. Hal ini menunjukkan bahwa model regresi menunjukkan distribusi normal. Pengujian menggunakan normal P-Plot dengan hasil sebagai berikut :

Normal P-P Plot of Regression Standardized Residual

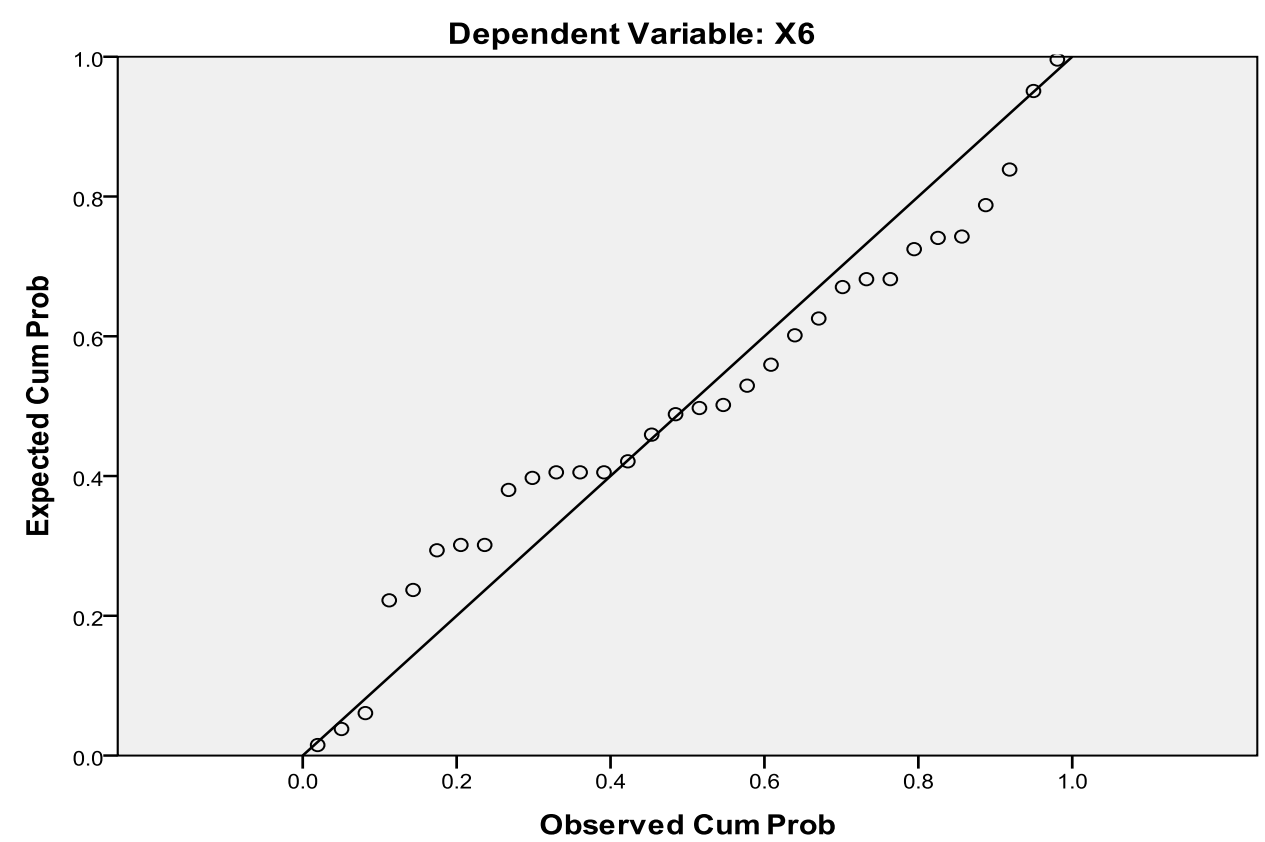

Gambar 2. Sketer plot 


\section{Uji Multikolinieritas}

Uji multikolinieritas dimaksud-kan untuk menguji apakah pada model regresi ditemukan adanya korelasi antar variabel independen. Model regresi yang baik seharusnya tidak terjadi korelasi antar variabel independen. Uji multikolinieritas menggunakan nilai VIF dan nilai Tolerance. Adanya multikolinieritas ditunjukkan oleh nilai tolerance $<0,1$ dan nilai VIF > 10 .

\section{Uji Multikolinieritas}

Tabel 6. Hasil Pengujian Multikolinieritas

\begin{tabular}{lll}
\hline & \multicolumn{2}{l}{ Collinearity } \\
& Tolerance & VIF \\
\hline Constant & & \\
$\mathrm{ECE}$ & .561 & 1.783 \\
$\mathrm{RMT}$ & .638 & 1.568 \\
$\mathrm{IAA}$ & .630 & 1.588 \\
$\mathrm{KK}$ & .754 & 1.327 \\
$\mathrm{PL}$ & .581 & 1.720 \\
\hline
\end{tabular}

Sumber: data diolah

\section{Uji Heteroskedastisitas}

Pengujian heteroskedastisitas menggunakan uji Glejser. Uji ini dilakukan dengan melakukan regresi terhadap nilai absolute residual. Jika variabel independen secara statistik signifikan mempengaruhi variabel dependen maka ada indikasi terjadi heteroskedastisitas. Hasil pengujian adalah sebagai berikut:

\section{Uji Heteroskedastisitas}

Tabel 7. Hasil Pengujian Heteroskedastisitas

\begin{tabular}{lllll} 
& & \multicolumn{2}{c}{ T } & Sig. \\
\hline 1 & (Constant) & 1.099 & .282 & \\
& ECE & .613 & .545 & \\
& RMT & .558 & .582 & \\
IAA & 4.710 & .000 \\
KK & -1.034 & .310 \\
PL & -.259 & .797 \\
\hline
\end{tabular}

Sumber: data diolah

\section{Goodness of Fit Model}

Uji Signifikansi Simultan

Uji F digunakan untuk melihat apakah variabel independen yang dimasukkan dalam model mampu berperan sebagai prediktor atas variabel dependen. Pengujian menggunakan SPSS 19 mendapatkan hasil sebagai berikut : 
Tabel 8. Hasil pengujian ANOVA

\begin{tabular}{llll}
\hline Model & F & Sig. \\
\hline 1 & Regression & 7.842 & $.000^{a}$ \\
& Residual & & \\
& Total & & \\
\hline
\end{tabular}

Sumber: data diolah 2012

\section{Koefisien Determinasi}

Koefisien determinasi digunakan untuk mengukur seberapa jauh kemampuan model dalam menerangkan variasi variabel independen. Berdasarkan hasil perhitungan didapatkan hasil sebagai berikut :

\section{Koefisien Determinasi}

Tabel 9. Hasil Pengujian Determinasi

\begin{tabular}{ll} 
Model & Adjusted R Square \\
\hline 1 & .525
\end{tabular}

Sumber : Data diolah

\section{Pengujian Hipotesis}

Langkah selanjutnya dalam penelitian ini setelah model regresi digunakan adalah melakukan uji hipotesis dan pembahasannya. Terdapat dua model regresi yang akan digunakan untuk pengujian hipotesis. Hasil yang diperoleh adalah sebagai berikut :

\section{HASIL UJI REGRESI LOGISTIK}

Tabel 10. Hasil Pengujian Regresi

\begin{tabular}{llll} 
Model & Beta & T & Sig. \\
\hline Costanta & & .449 & .657 \\
EF & .077 & .425 & .674 \\
\hline
\end{tabular}

Sumber: Data diolah

\section{Hasil Uji Regresi Berganda}

Tabel 11. Hasil pengujian regresi berganda

\begin{tabular}{llll}
\hline Model & B & $\mathbf{t}$ & Sig \\
\hline Costanta & 7.879 & 1.099 & .282 \\
ECE & .148 & .613 & .545 \\
RMT & .133 & .558 & .582 \\
IAA & 1.283 & 4.710 & .000 \\
KK & -.301 & -1.034 & .310 \\
PL & -.052 & -.259 & .797 \\
\hline
\end{tabular}

Sumber: data diolah 
H1 :Terdapat interaksi positif dan signifikan antara persepsi keadilan organisasi terhadap employee fraud yang dimoderasi kualitas prosedur pengendalian internal.

$\mathrm{H} 2 \mathrm{a}$ :Terdapat hubungan positif dan tidak signifikan antara ethical corporate environment dan kualitas prosedur pengendalian internal.

$\mathrm{H} 2 \mathrm{~b}$ :Terdapat hubungan positif dan tidak signifikan antara risk management training dan kualitas prosedur pengendalian internal.

H2c :Terdapat hubungan positif dan signifikan antara internal audit activities dan kualitas prosedur pengendalian internal.

H2d :Terdapat hubungan negatif dan tidak signifikan antara kesesuaian kompensasi dan kualitas prosedur pengendalian internal.

H2e :Terdapat hubungan negatif dan tidak signifikan antara power leadership dan kualitas prosedur pengendalian internal.

Penelitian ini menguji faktor-faktor yang mempengaruhi kualitas prosedur pengendalian internal dalam memoderasi hubungan antara persepsi keadilan organisasi terhadap employee fraud. Secara keseluruhan hasil pengujian hipotesis dengan menggunakan regresi berganda untuk menguji faktor-faktor yang mempengaruhi kualitas prosedur pengendalian internal dan regresi logistik untuk menguji hubungan persepsi keadilan organisasi terhadap employee fraud yang dimoderasi kualitas prosedur pengendalian internal dapat dilihat pada tabel berikut ini.

Tabel 12. Ringkasan hasil pengujian hipotesis

\begin{tabular}{|c|c|}
\hline Hipotesis & Hasil \\
\hline $\mathrm{H} 1$ & Ditolak \\
\hline $\mathrm{H} 2 \mathrm{a}$ & Ditolak \\
\hline $\mathrm{H} 2 \mathrm{~b}$ & Ditolak \\
\hline $\mathrm{H} 2 \mathrm{c}$ & Diterima \\
\hline $\mathrm{H} 2 \mathrm{~d}$ & Ditolak \\
\hline $\mathrm{H} 2 \mathrm{e}$ & Ditolak \\
\hline
\end{tabular}

\section{KESIMPULAN DAN SARAN}

Hasil uji statistik persepsi karyawan pada perusahaan manufaktur di Semarang terhadap employee fraud yang dimoderasi kualitas prosedur pengendalian internal menggunakan regresi logistik dan faktor-faktor seperti ethical corporate environment, risk management training, internal audit activities, kesesuaian kompensasi dan power leadership dengan menggunakan regresi berganda dapat disimpulkan

a) Terdapat interaksi positif dan tidak signifikan antara persepsi keadilan organisasi terhadap employee fraud yang dimoderasi kualitas prosedur pengendalian internal.

b) Terdapat hubungan positif dan tidak signifikan antara ethical corporate environment terhadap kualitas prosedur pengendalian internal.

c) Terdapat hubungan positif dan tidak signifikan antara risk management training terhadap kualitas prosedur pengendalian internal.

d) Terdapat hubungan positif dan signifikan antara internal audit activities terhadap kualitas prosedur pengendalian internal.

e) Terdapat hubungan negatif dan tidak signifikan antara kesesuaian kompensasi terhadap kualitas prosedur pengendalian internal.

f) Terdapat hubungan negatif dan tidak signifikan antara power leadership terhadap kualitas prosedur pengendalian internal. 


\section{Keterbatasan}

Evaluasi hasil penelitian ini mempertimbangkan beberapa keterbatasan yang mungkin timbul sehingga dapat mengurangi tingkat validitas dan reliabilitas hasil penelitian ini, yaitu tingkat responden yang rendah hanya $31,37 \%$ mengakibatkan hasil penelitian tidak dapat mewakili keseluruhan populasi yang ada dan tingkat responden top management seperti General Manager dan Direktur sangat rendah hanya 3,13\% dan 9,375\% mengakibatkan hasil penelitian tidak dapat mewakili pendapat mengenai power leadership.

\section{REFERENCES}

Albrecht, W. S. and Romney, M. B. (1980), "Deterring White-Collar Crime in Banks", The Bankers Magazine 163: 60.

Blaszczynski, A. and McConaghy, N. (1994), "Criminal Offences in Gamblers Anonymous and Hospital-treated Pathological Gamblers", Journal of Gambling Studies 10, 99-127.

Clarence, Y. K. N. (2005), "White-Collar Crime is on the Rise in Malaysia, with Perpetrators Becoming More Sophisticated. Are Our Laws Sufficient Deterrents?", AsiaViews. Edition: $07 / \mathrm{II} / \mathrm{Feb} / 2005$.

Crofts, P. (2002), Gambling and Criminal Behaviour: An Analysis of Local and District Court Files. Sydney: Casino Community Benefit Fund.

Goldstraw, J., Smith, R.G. and Sakurai, Y. (2005), "Gender and Serious Fraud in Australia and New Zealand", Trends and Issues in Crime and Criminal Justice 292. Australian Institute of Criminology: Canberra.

Hery (2004), "Persepsi Top Executive (Sektor Publik dan Swasta) terhadap Fungsi Internal Audit", Journal Media Riset Akuntansi, Auditing \& Informasi,Vol. 4, No. 1 April 2004:23-41.

Ikatan Akuntansi Indonesia, Standar Profesional Akuntan Publik, 2006. Jakarta: Salemba Empat Jerry, W. L., Mark, I. H. and Jack, D. B. (2003), "A Fuzzy Neural".

KPMG Forensic, 2004, "Fraud Survey 2004", KPMG International, Amsterdam

Mulyadi (2002), Auditing, Edisi 6. Network for Assessing the Risk of Fraudulent Financial Reporting", Managerial. Auditing Journal 18: 657-665.

Tuanakotta, T. M. (2007). Akuntansi forensik dan audit investigatif. Jakarta: Fakultas Ekonomi Universitas Indonesia. 